\title{
Delving into the Determinants of Default Risk in Savings Groups: Empirical Evidence from Ecuador
}

\author{
Pilar López-Sánchez ${ }^{1}(1) \cdot$ Elena Urquía-Grande ${ }^{2} \oplus \cdot$ Cristina del Campo $^{2}(1) \cdot$ \\ Andrés L. Cancer ${ }^{3}$
}

Accepted: 23 September 2021 / Published online: 11 November 2021

(c) European Association of Development Research and Training Institutes (EADI) 2021

\begin{abstract}
Financial inclusion has been broadly recognized as critical in alleviating poverty and achieving inclusive economic growth. The capability of borrowers to repay their microcredit loans is a critical concern and is the first risk of Microfinance institutions sustainability. Exploring the determinants of credit risk is an issue of substantial importance in microfinance. The purpose of this research was to identify the savings group members' characteristics that have impact on default risk. We have used a multivariate regression model to identify the factors that affect default behaviour among microcredit borrowers from savings groups. We have analysed a sample of more than different 400 Savings Groups and 7251 active users of the "Saving and Learning" program in Ecuador. Empirical results demonstrated that factors such as seniority, accumulated savings and the number of members in the savings groups are determinant variables of default risk. The significant positive sign on variable "Gender" is consistent with the previous authors that indicate that the probability of having problems in loan repayment is higher for males than for females. The generalizability of our findings should, of course, be interpreted with caution, as they may be idiosyncratic of the sample, period or region. To contrast and contextualize these results, we had in-depth discussions with the Savinco managers and their field agent in Ecuador. There are many contributions. For practitioners, relevant factors that can affect savings groups default rates have been identified. For academics, the rich information provided by the Savinco mobile App could be a starting point for further quantitative research.
\end{abstract}

Keywords Formal and Informal sectors · Financial Markets: Savings and capital investments $\cdot$ Household savings, borrowing, debt and wealth $\cdot$ Technological Change $\cdot$ Latin America, Ecuador

JEL Classification G51 $017 \cdot 033 \cdot 016 \cdot 054$

Pilar López-Sánchez

p.lopez.prof@ufv.es

Extended author information available on the last page of the article 


\section{Résumé}

Il est largement reconnu que l'inclusion financière est essentielle pour réduire la pauvreté et parvenir à une croissance économique inclusive. La capacité des emprunteurs à rembourser leurs prêts de microcrédit est une préoccupation essentielle et constitue le premier risque pour la pérennité des institutions de microfinance. L'étude des déterminants du risque de crédit est une question d'une importance capitale en microfinance. Le but de cette étude est d'identifier les caractéristiques des membres de groupes d'épargne qui ont un impact sur le risque de défaut de paiement. Nous avons utilisé un modèle de régression multivariée pour identifier les facteurs qui affectent le comportement de défaut de paiement parmi les emprunteurs de microcrédit au sein de groupes d'épargne. Nous avons analysé un échantillon de plus de 400 groupes d'épargne différents et 7251 utilisateurs actifs du programme « Épargne et apprentissage » en Équateur. Les résultats empiriques ont démontré que des facteurs tels que l'ancienneté, l'épargne accumulée et le nombre de membres dans les groupes d'épargne sont des variables déterminantes du risque de défaut de paiement. Sur la variable «Genre », le signe positif significatif est cohérent avec les études précédentes qui indiquent que la probabilité d'avoir des problèmes de remboursement de prêt est plus élevée chez les hommes que chez les femmes. Bien entendu, le caractère généralisable de nos résultats doit être interprété avec prudence, car ces résultats peuvent être uniques à l'échantillon, à la période ou à la région. Pour contraster et contextualiser ces résultats, nous avons eu des discussions approfondies avec les gestionnaires de Savinco et leur agent de terrain en Équateur. Les contributions sont nombreuses. Pour les praticiens, ont été identifiés les facteurs pertinents pouvant affecter le taux de défaut de paiement des groupes d'épargne. Pour les universitaires, les riches informations fournies par l'application mobile Savinco pourraient être un point de départ pour d'autres études quantitatives.

\section{Introduction}

Despite the important growth of microfinance over the last decades, there is a profound debate about its effectiveness as a development tool, the impact on the more vulnerable population, and the roles of the private and public sectors in poverty reduction (Karnani 2011, 2017; Mader 2013, 2017). Although there has been immense progress in the level of financial inclusion, measured by the number of accounts, there are still 1.7 billion adults (31\% of the global adult population) excluded from the financial sector. The profile of the unbanked usually consists of low net-worth individuals, mainly woman, living in rural areas and with little or no collateral (Demirgüc-Kunt et al. 2018). In addition to this, financial inclusion must be measured not only by access to financial products but, more importantly, by their quality and use, placing the focus on financial health and not only on financial inclusion (Arellano et al. 2019; Karlan et al. 2017). Given the difficulty for formal microfinance institutions to reach the rural poor, money lenders are sometimes the only finance solution for this vulnerable population (Madestam 2014), therefore in the past few years, foundations and non-profit organizations (NPO) have placed efforts into promoting informal finance solutions such as Self-Help Groups (SHGs) 
or Savings Groups (SGs) to help improve financial inclusion of the rural poor (Giné and Karlan 2014; Kodongo and Kendi 2013; Adusei 2013; Bouman 1983). The rationales of these type of models are such that members of the group simultaneously save, lend and apply for credit and since borrowers know each other, this mitigates adverse selection problem and repayment. In addition, group meetings facilitate education and training, helping members with small experience to improve their businesses financial performance (Armendáriz and Morduch 2005). Moreover, groups contribute to the empowerment of women helping them sustain their homebased microenterprises (Duflo 2012). Although group micro-lending has been a successful idea in many parts of the world, it can be expensive given the additional cost of group formation, training, group procedures and monitoring of regular meetings where instalments are paid (Savita 2007).

Recently, new actors have come into this market aiming to improve the model of traditional informal Savings Groups by the development and use of new Information and Communication Technologies (ICTs). One of these actors is Savinco Social Finance (Savinco) promoted by Expert Timing Systems (ETS) ${ }^{1}$ a Spanish high-tech company specialized in quantitative finance. Savinco mission is to improve socioeconomic inclusion of the most vulnerable population in Latin America by promoting community savings, a solution based on four pillars: self-financing through savings, self-management, financial education and technology. The technological pillar includes the development of an advanced cloud-mobile App, Qmobile, to monitor group financial transactions. The purpose of the App is to help group members to manage their monthly meetings more efficiently (savings, paid-in capital, loans, received and due interest) and to improve financial education by new innovative cost-effective teaching contents and methods.

In this paper, we analyse the information provided by one of the most active savings groups programs in Ecuador named "Saving and Learning" designed and managed by Savinco. The purpose of this research is to identify which variables determine the sustainability of savings groups and the profile of customers that could default on loan payments based on the information provided by the cloud-mobile App. Even though the meaning of Default and Non-performing loans are not exactly the same, we will be using both terms indistinctly throughout the paper. The database includes information of over 400 savings groups and 9000 customers during the period 2014-2020.

By using real user's data, this paper defines the following research questions:

RQ1 What are the determinants of savings group members default risk?

RQ2 Does gender influence default on loan repayments?

This research has the following structure: In "State of the Art" section, we discuss the literature and contextualize the origin of Microfinance and Savings Groups

\footnotetext{
1 https://www.etsfactory.com/.
} 
followed by a description of the Savinco's "Saving and Learning" program in Ecuador. "Sample and Model Specifications" section presents the data, instrument and method used for the analysis. "Results" section provides the results. "Findings Discussion" section includes findings discussion and "Conclusions". As interesting results, we can highlight variables such as group seniority, accumulated savings, number of members and average loan term that can affect default risk. Additionally, as conclusions for academics can be that the rich information provided by the Mobile App, Qmobile, could be a starting point for further quantitative research. Finally, we highlight the importance of the use of technology to improve savings groups' efficiency and survival. Future lines of research include the design of a credit scoring for groups and individuals that will help them enter formal financial institutions together with a post-COVID impact analysis.

\section{State of the Art}

\section{Microfinance Evolution}

Financial inclusion has been broadly recognized as critical in alleviating poverty and achieving inclusive economic growth. Undeniably, there is a close relationship between economic development and financial inclusion (Deb and Kubzansky 2012). Demirgüc-Kunt et al. (2018) showed in the Global Findex 2017 that between 2011 and 2017 the number of people with a bank account grew by 1.2 billion worldwide. However, 1.7 billion adults (31\% of the global adult population) remain unbanked, most of whom are women living in rural areas in developing countries. Other important results of the Global Findex 2017 are the most common reason for not having an account. The principal one is the lack of money, $66 \%$ of adults without an account identified this as the primary reason, and $20 \%$ said it was the only reason. Other reasons include (in order of diminishing importance) no necessity for an account; accounts are too expensive; financial institutions are located too far away; lack of enough credit information; lack of trust in financial institutions and religious reasons (Mookherjee and Motta 2016; Giné and Karlan 2014; Karlan et al. 2014). In other occasions, the problem is that they are excluded by other members of the group (Marr 2004; Hulme and Mosley 1996). However, there is also the case that although they are creditworthy, micro-entrepreneurs have no interest in borrowing from formal institutions because they do not understand or trust the banking system (Ciravegna 2006) or they do not have a "savings culture" (Adusei 2013; Ashraf et al. 2006; Benartzi and Thaler 2004; Duflo et al. 2006; Van Rooyen et al. 2012).

The absence of formal financial institutions in rural areas drove Yunus to develop the idea of microcredit in the early 80s in Bangladesh (Yunus 2003). In its original vision, the microfinance concept consisted of giving small loans, primarily to female entrepreneurs at the bottom of the pyramid, for productive and survival purposes. These women were unserved by the regular banks because of the lack of collateral or simply because they did not have easy access to banks. The primary purpose was to provide an alternative way of finance to the oppressive regime of traditional moneylenders, which was the only source of credit available to the most vulnerable 
population. Moneylenders were viewed as exploitative of poor borrowers, often charging usurious interest rates (Mookherjee and Motta 2016; Pellegrina 2011). Yunus's proposal was based on the idea of the close relationship between economic development and financial inclusion (Deb and Kubzansky 2012). The final purpose of providing access to financial services to the unbanked population was to improve the quality of life of the more vulnerable and to promote entrepreneurship as a way out of poverty (Morris et al. 2018).

The core of Grameen's innovation was “the group". The group-based approach enables poor people to accumulate capital by way of small savings and facilitates their access to informal credit facilities. Borrowers at most Microfinance Institutions (MFIs) were organized into groups which have joint liability; if anyone in the group is unable to repay its loan each other member of the group should pay for some portion of the loan obligation. This system promotes close monitoring of individual behaviour by the group (Karlan 2007; Ghatak 2000). Group borrowers tend to be less delinquent than individual borrowers (Mokhtar et al. 2009).

The second Yunus's core purpose was the focus on women because they are more vulnerable. Worldwide women have been historically disadvantaged in terms of education, social exclusion, discrimination, and access to assets or other resources (Demirgüc-Kunt et al. 2018; Raihan and Uddin 2018; Fafchamps et al. 2011; Pitt and Khandker 1998). In addition, women are considered better administrators than men and are more concerned about their families. FMBBVA (2019) stated that supporting women means supporting the following generations. Although women's access to credit has improved in the last few years, there is still a strong gap between women and men (Demirgüc-Kunt et al. 2018). Currently, following the United Nations 2030 Sustainable Development Goals (United Nations 2015), various policies and support mechanisms are being implemented to elevate the status of women to fulfil international recommendations. Finally, Microcredit groups usually have weekly or monthly meetings where members repay their loan instalments and serve both as a social occasion and as an opportunity to receive financial literacy training.

MFIs have expanded rapidly all around the world, according to the Microfinance Barometer 2018, reaching 139 million low-income clients with a loan volume of US $\$ 114$ billion in 2017. Lately, MFIs have undergone a huge transformation, offering a wider range of financial products and services and many of them have become formal/regulated institutions (e.g. Gutierrez-Nieto and Serrano-Cinca 2019; Giné and Karlan 2014; Van Rooyen et al. 2012; Hermes and Lensink 2009 among others).

However, in the last decade, Yunus's vision has been questioned because of the proliferation of MFI's applying aggressive lending practices to extend the borrower base. As a result, there were "over-indebtedness" and "loan overlapping", meaning, borrowers taking loans from one MFI to pay back another (Haldar and Stiglitz 2016). In 2011, India's SKS Microfinance ambitious project produced a serious MFI's repayment crisis and trust on these institutions (Mader 2013, 2017; Ghosh and Ray 2016; Pole et al. 2014). Moreover, although much economic and financial literature has highlighted the importance of microfinance as a factor in development, there is an intense debate about its effectiveness as a development tool given the multidimensional components of poverty (Maity 2019; Ditcher 2007). Some researchers even suggest that microcredits may have a negative impact on the most 
vulnerable (Cull et al. 2018; Bateman and Chang 2009; Vogelgesang 2003; Prahalad and Hammond 2002) with over-indebtedness and lack of financial education being some of the main problems (Bali and Varghese 2013; Berge et al. 2012). Authors like Gutiérrez-Nieto and Serrano-Cinca (2019) believe microfinance is a robust banking idea but not as an anti-poverty intervention on its own. Pollin and Feffer (2007) suggested that credit accessible to poor people is a laudable aim, however, as a tool against global poverty, microcredit should be judged by its effectiveness.

Currently, a profound digital revolution is taking place, characterized by unstoppable technological advances (Ochoa et al. 2016). This digital revolution not only affects mobile communications and new ICT solutions, but also the microfinance industry. Mobile phones, and other technological devices, had an exponential increase in recent years; this is mainly due to the global investment in mobile network and the design of low-price devices. Seven out of ten homes belonging to the poorest $20 \%$ of the population have a mobile phone (GSMA 2019; Global Microscope 2019). Ontiveros et al. (2014) claim that increasing digitization of financial services provides enormous potential for improving financial inclusion with lessexpensive financial services models, more accessible and efficient, such as branchless banking models or mobile payment with simple text-based phones.

Microfinance Institutions can be classified in three different groups: deposit-taking institutions like commercial banks, credit-only non-deposit-taking institutions, and informal organizations. The latter category includes savings groups (SGs), club pools and financial services associations and this is the area where we are going to concentrate our research (Kodongo and Kendi 2013; Kirkpatrick and Maimbo 2002). The purpose of these informal organizations is to provide finance to the population that is excluded from the formal financial sector.

\section{Savings Groups}

In recent years and parallel to the development of the microfinance industry, many non-profit organizations (NPOs) and social enterprises have begun to promote savings-lending groups among the more vulnerable population. Nelson (2013) suggests that savings groups must be the starting point for financial inclusion. These savings groups (SGs) emulate and improve Yunus's original idea of voluntary formed groups of borrowers applying for credit with joint liability (Yunus 2003).

Foundations and development organizations have mobilized over 700,000 savings groups in vulnerable communities across 75 countries worldwide (Allen 2018). A systematic review of 53 studies conducted between 2004 and 2017, carried out by Gash (2013, 2017), concludes that SGs have a positive impact on household savings, access to credit, asset accumulation, consumption, business investment and social capital. Thus, SGs are considered a first step for unbanked customers to become formally financial included (Ballem et al. 2012). So, when SG's members demonstrate their capacity to repay their debts, bank loans can be accessible for them.

SGs were originated from the Rotating Savings and Credit Associations (ROSCA) that was described by Bouman (1983) as "the poor man's bank". ROSCA are created on informal appreciation among friends or family and tend to have 
simple structures. Each SG acts as a financial institution owned and managed by the group members. The basic element is the group, and the most effective component is the "forced" saving element. Members regularly contribute money to a common pot that is assigned to each member in turn. Most of the time, the order is predetermined. The group meets regularly for the repayment of loans, and allocation of proceeds. Money is not idle for long but changes hands rapidly, satisfying both consumption and production needs (Gugherty 2007; Armendáriz and Morduch 2005). The risks of this system are the difficulty to increase the size of the resources, the impossibility to move resources across communities, the right allocation of resources when the pot is excessive and the high interest rates. The ROSCA concept has been adapted to the needs and characteristics of different countries (Gigante 2017; Umuhire 2013; Ardener 1964) so that some sort of short-term savings club can be found in most low-income communities around the world. For example, the denominated "Tontine" in rural Cameroon, where members contribute with a fixed amount that is assigned fully to one of its members (Nzemen 1988). In Asia, a "Hui" is organized in a way that members can bid for the pot (Ardener 1964). The system called "Likelemba", mostly used in the Democratic Republic of Congo, is a common container or "pot" assigned to one of the group members, it works as a "turbine" where the money flows from one group member to the next in the following meeting (Urquía-Grande et al. 2017). In Latin America, the most common format is the mutuality which is called differently along the countries: for example, "Tanda" in Mexico and "Polla" in Chile. Mutualities are more organized and have more rigid structures than a family group (Armendáriz and Morduch 2005).

SGs are informal associations consisting of 10 to 20 members, usually women from similar social backgrounds, that have voluntary come together with the purpose of improving their economic situation out of mutual help, solidarity and joint responsibility (Wydick et al. 2011). Some of the SGs characteristics are small-sized memberships, homogeneity of composition, cohesiveness and effective participation of members in the functioning of the group (Husain et al. 2010). Additionally, usually SGs offer poor women a platform to receive information regarding financial education, health, nutrition and governance (Shivaprasad 2020; Navajas et al. 2000). The majority of the SGs are promoted and driven by NPOs.

Most of these types of SGs follow the same three basic principles: joint liability, regular meetings and no grants in the common "pot", only members' savings. Joint liability means that if anyone in the group is unable or unwilling to repay, each member of the group should pay for some portion of the loan obligation. Joint liability increases repayment because borrowers know each other and try to avoid risky profiles. An incentive for the repayment of group loans is the joint liability. Repayment improves among borrowers with strong social ties and deteriorates among borrowers with weak social ties (de Quidt et al. 2016; Maria 2009; Conning 2005). In addition, group reputation could affect individual credit rating for future access to credit. Attanasio et al. (2013) suggest that joint liability will also prevent borrowers from using loans for non-investment purposes.

The second principle, and probably the most important, is the regular meetings. Initially conceived for screening the repayment of loans, they are also used for facilitating member training on financial and business skills and monitoring loan use. 
Feigenberg et al. (2014) found out that an increase in the meeting frequency created social capital, which led to a subsequent improvement in repayment rates.

The third principle is that there are no grants in the common pot, only member's savings. All the money in the pot is put together and is allocated for different borrowers each time. This group-lending model is becoming more flexible in relation to the quantity of the contributions and the fact that participants could be entitled to the loan without waiting for their turn.

Dellien et al. (2005) discuss key differences between group lending and individual lending regarding screening and monitoring. In Savings groups, the group pressure, and social ties reduce repayment risk, while individual lending repayment discipline is created by strict enforcement of contracts.

SGs relational model is very intensive in terms of transactions, given the number and size of loans, and the number of repayment sessions, therefore transaction cost can be very high (Karlan 2007). As a result, it is necessary to promote the use of technology to maintain a proper bookkeeping and accounting system to help controlling the regular meetings transactions (receipts, vouchers, cash books, members individuals' books) as the time consumed in meetings.

\section{Default Risk}

The capability of borrowers to repay their microcredit loans is a very important issue and is the first risk of MFI's sustainability. Default is a failure to repay a debt including interest or principal on a loan or security and can occur when a borrower is unable to make timely payments, misses payments or stops making payments. Default not only causes a reputational effect on the group but also has an impact towards future borrowing capacity and group formation. Individuals and businesses can fall into default when they are not able to keep up with their debt obligations. A high rate of non-performing loans (NPL) is one of the main causes of bank failures. Exploring the determinants of ex-post credit risk is an issue of substantial importance for financial stability and for bank's management (Reinhart and Rogoff 2010). However, factors affecting loan delinquency in microfinance can be dramatically different from developed countries (Kodongo and Kendi 2013; Field et al. 2010). In contrast to commercial banks, microfinance institutions cannot secure loans with collateral or screen borrowers, given the lack of assets or reliable financial information. MFIs prefer to offer group-lending contracts when the size of the loan is high, transferring the monitoring role to the group of borrowers (Giné and Karlan 2014; Maria 2009).

Potential factors determining loan delinquency among microfinance customers have been widely covered in the literature (Baland et al. 2017; Beg and Bashir 2017; Muthoni 2016; Field and Pande 2008; Adongo and Stock 2005; Churchill 2004; Norell 2001 among others). These factors include interest rates, age, loan amount, repayment period and loan category (group or individual). In relation to loan category, Kodongo and Kendi (2013) suggest that group-lending programs are more effective than individual lending programs in mitigating the risk of default. Individual loans are three times more likely to default on their 
microcredit obligations than group borrowers, the reason being that, although everyone is responsible for repaying their own loans, if any member defaults, other members will have to repay the loan (Baland et al. 2017). Al-Azzam et al. (2012) empirical analysis suggests that peer monitoring, group pressure and social ties reduce delinquency. In addition, group lending allows MFIs to identify individuals within the groups whose credit risk has improved and offer them progressive individual loans.

Another factor of discussion in loan default risk is group gender composition (Banerjee et al. 2015; Giné and Karlan 2014; Adusei 2013). A higher percentage of female clients in MFIs are associated with a lower portfolio risk, fewer write-offs and fewer provisions (D'Espallier et al. 2011). Eckel and Grossman (1998, 2002) find that women are more cooperative than men and their behaviour is less selfish. In theory, females have a stronger internalization of pro-social values than men; therefore, it would be expected that women might be less likely to default on their loan payments. Furthermore, repayment of loans represents one kind of cooperative behaviour. When tension exists between the individual interest and the welfare of the group, women are more likely to make choices that contribute to group welfare. In addition, people tend to behave in accordance with those around them even against their own interest (de Mel et al. 2009; Hermes and Lensink 2009; Anthony and Horne 2003). The influence of some members of other group can influence other members (Karlan et al. 2014, 2017; Prina 2015).

In relation to group sizes there are different theories. Ahlin (2015) highlights the benefits of larger group size based on the intragroup monitoring role, while other authors such as Conning (2005) argue that too large groups with loose social ties may not be able to enforce the cooperative agreements necessary for group repayment.

In terms of age, Mokhtar et al. (2009) and Bhatt and Tang (2002) suggest that older borrowers are more responsible and disciplined in repaying their loans than younger borrowers. The lack of experience in the business involved could be one of the reasons for younger borrowers not to repay their loans.

The amount of the loan and terms are other factors that can affect client delinquency (Norell 2001). Mirpourian et al. (2016) consider that repayment rates increase as borrowers get closer to the loan limit. Some authors like Field and Pande (2008) explain that a less rigid repayment schedule would decrease default rates. The problem is not the loan term but the repayment capacity. MFIs should consider lowering the weekly repayment amount and providing longer duration of payments in response (Mokhtar et al. 2009).

Many authors consider interest rates one of the most important factors in microfinance default risk (Le Polain et al. 2018). In fact, savings groups were born to serve the unbanked and to protect them from the abusive interest rates charged by moneylenders. Group-lending interest rates were lower than individual lending because group joint liability reduce default risk. Authors such as Kodongo and Kendi (2013) confirm that high interest rates increase the chances of client delinquency. Other authors consider that high interest rates are necessary for first time borrowers. There are also dynamic individual contracts that involve a "penalty" interest rate after default, and favourable rates after success (Ahlin and Waters 2014). 
Ultimately, the lack of financial skills is one of the main problems for microentrepreneurs when managing their micro-business. It has been proven that financial education improves microcredit beneficiaries' financial outcomes (López-Sánchez et al. 2020; Drexler et al. 2014; de Mel et al. 2014; Deb and Kubzansky 2012; Karlan and Valdivia 2011). The impact of training programs improves when tuition is adapted to the micro-entrepreneur's needs.

Finally, other factors could be taken into account as determinants of default risk such as inflation rates (Owusu-Manu et al. 2016), weather conditions (Golden et al. 2007), financial, health (Ashraf 2020) or political crisis (Cuadra and Sapriza 2008) occurring in a country. However, in this research these will not be taken into account as they are considered too macroeconomic and volatile for the constructed model.

\section{Ecuador}

The economy of Ecuador is the eighth largest in Latin America with a GDP of 107.4 billion dollar and mainly lives from agriculture and oil. In the past few years, Ecuador has been facing serious economic and social problems, such as large inequality gaps, informal economy and low income. Likewise, access to credit, availability of ATMs or Internet access is very low in rural areas (ASOMIF Ecuador 2019).

The Global Microscope has been building for years a ranking of countries in relation to the enabling environment for financial inclusion, which consists of a weighted and dynamic model of assigning scores to a series of selected indicators. During the past few years, Ecuador has had a significant deterioration in the Global Microscope ranking. It has gone from a sixth outstanding position in the 2009 to the 26th position in 2019. The main cause of this deterioration is the lack of a political environment to ensure the provision of affordable and quality financial services in the country and that Ecuador does not have a national strategy for financial inclusion or concrete plans for the digital transformation of the country (Global Microscope 2019).

The difficulties to access formal credit in rural areas have led to the creation of informal intermediaries such as savings groups. Groups of people, mainly women, that save and periodically contribute a quantity of money to a common "pot" that will give loans among their own members. The effectiveness of savings groups is based mainly on the social sanctions that occur if a member of the group does not pay back its loan. A limitation of this model lies in the low amounts of savings and credit generated (Bicciato et al. 2020).

We chose Ecuador because of the dramatic economic situation together with the importance of Saving Groups in microfinance programs in the country. 


\section{Sample and Model Specifications}

Savinco designed a program called "Saving and Learning" based on the community lending groups model with the purpose of starting a trend of self-sustainable improvement in the quality of life of families living in poverty. Savinco applies a self-finance and self-managed socio-economic inclusion model, which starts by promoting community savings. This solution is based on four pillars: financial education, self-financing through savings, self-management and technology. The main beneficiary of SGs has been the most vulnerable population.

These types of programs are intensive in terms of human resources, given the high number of transactions in the regular meetings. As a result, Savinco decided to apply new ICTs to make the management of the meetings more accessible, convenient and safe and developed an advanced cloud-mobile technology called Qmobile. This online platform main purpose was to help group members to manage their regular meetings more efficiently, helping them recoding all financial transactions (savings, paid-in capital, loans, received and due interest). In addition, Qmobile is used to improve financial education, to monitor group-lending transactions and to evaluate impact on vulnerable populations. Savinco implemented the "Saving and Learning" program in Peru and Ecuador. Ecuador program is the largest one with over 400 savings groups and over 9000 active members managed by the groups themselves with the advice of coaches.

Savinco provided the authors with access to data already anonymized for the total "Saving and Learning" Ecuadorian program members in such a way that the data subjects would not be identifiable. Concretely, the only personal available data for each individual are their gender and age together with some of their financial history within the program, ensuring each individual's privacy is protected.

Hence, using the data from the Ecuadorian cloud-mobile SAVINCO platform Qmobile from the year 2014 to 2020, we have tried to answer our research questions. The initial sample consisted of the 9392 active users of the Ecuadorian microcredit app Qmobile on the extraction date of 6 February 2020. However, there were some profiles with some missing data related to age and birth dates that could not be estimated, without a history of borrowing and/or with less than three or more months of seniority so they were not considered in the analysis. Hence, the working sample consisted on 7251 users. Gender distribution of those remaining 7251 users can be seen in Fig. 1. Most of those users were females (70.8\%), which is common in this type of informal savings institutions. 
Fig. 1 Distribution by gender

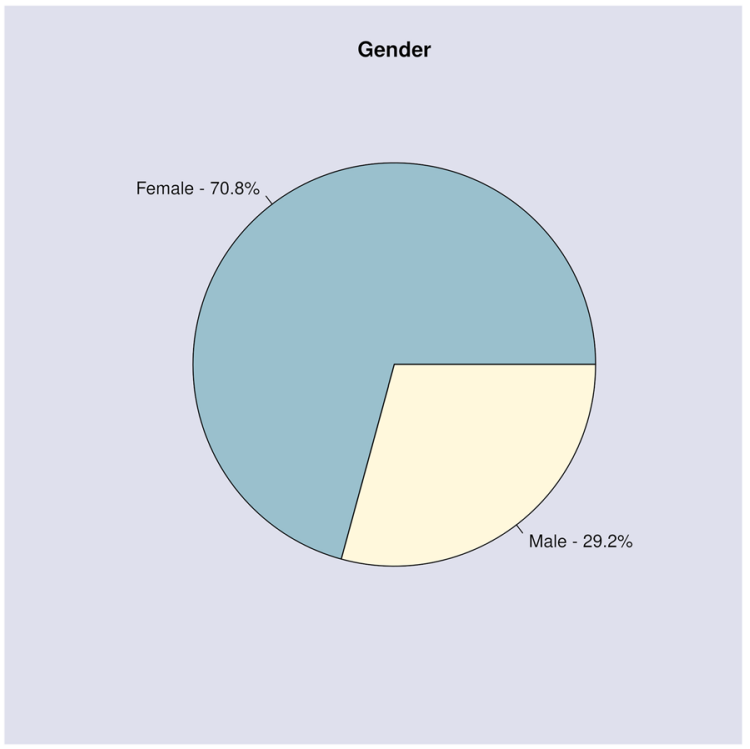

\section{Model Specification: Dependent Variable}

As it was stated before, we are interested in analysing the possibility of the users of this Ecuadorian microcredit app Qmobile to incur in non-performing loans (NPL). In banking, commercial loans are usually considered NPL if the borrower is 90-180 days past due, however, Qmobile classifies a loan as NPL as soon as the user fails to meet his/her monthly instalment. Nevertheless, most users regularize their situation in the following group meeting, so that the most usual term for NPL duration is the month between consecutive meetings. Among Qmobile Ecuador app users the NPL rate is quite small (see Table 1) as the users with no history of NPL behaviour are $94.79 \%$ of the total active users.

Due to our interest in studying whether microcredit borrowers incurred in NPL, we transformed this variable counting the number of times a user is past due into a binary one. Therefore, our dependent variable (NPL) represents the user's credit status, with value 1 denoting existence of NPL and 0 standing for the on-time repayment of all previous loans.

\section{Model Specification: Independent Variables}

There are several aforementioned variables that the literature identifies for being the most prominent loan repayment determinants in the microfinance industry. The

Table 1 NPL frequencies and percentages

\begin{tabular}{lllllllllllll}
\hline 0 & 1 & 2 & 3 & 4 & 5 & 6 & 7 & 8 & 9 & 10 & 11 & 12 \\
\hline 6873 & 241 & 67 & 25 & 17 & 11 & 6 & 5 & 1 & 2 & 1 & 1 & 1 \\
$(94.79 \%)$ & $(3.32 \%)$ & $(0.92 \%)$ & $(0.34 \%)$ & $(0.23 \%)$ & $(0.15 \%)$ & $(0.08 \%)$ & $(0.07 \%)$ & $(0.01 \%)$ & $(0.03 \%)$ & $(0.01 \%)$ & $(0.01 \%)$ & $(0.01 \%)$ \\
\hline
\end{tabular}


Table 2 Variables considered in the study

\begin{tabular}{lll}
\hline Code & Description & Possible values \\
\hline X1. Gender & User's gender & Female \\
X2. Rural & Male & Yes \\
& & No \\
X3. Received loans & User's number of previously received loans & Discrete variable \\
X4. Seniority & User's number of months in the group & Discrete variable \\
X5. Age & User's age measured in years & Discrete variable \\
X6. Average loan term & Average term of all the loans the user has had in the & Discrete variable \\
& past measured in months & \\
X7. Average loan & Average amount (\$) of all the loans the user has had & Continuous variable \\
& in the past & \\
X8. Total received amount & Total amount (\$) that the user has borrowed in the & Continuous variable \\
& past & \\
X9. Accumulated savings & User's accumulated savings (\$) & Continuous variable \\
Z1. Current capital & Group capital at data extraction (\$) & Continuous variable \\
Z2. Initial capital & Group capital at founding (\$) & Continuous variable \\
Z3. Current female percent & Group percentage of females at data extraction & $0-1$ \\
Z4. Initial female percent & Group percentage of females at group founding & 0-1 \\
Z5. Group life & Group life measured in months & Discrete variable \\
Z6. Current members & Group number of members at data extraction & Discrete variable \\
Z7. Initial members & Group number of members at group founding & Discrete variable \\
\hline & &
\end{tabular}

following variables will be included in our model as independent variables. A brief explanation of each variable is given in Table 2 and, to facilitate understanding and identification, codes $\mathrm{X} 1$ to $\mathrm{X} 9$ are assigned for variables related to users and $\mathrm{Z} 1$ to $\mathrm{Z} 7$ for variables related to groups.

Although interest rates are a determinant variable mentioned by several papers (e.g. Ahlin and Waters 2014; Kodongo and Kendi 2013), in our model they are not included, because in our sample all customers bear the same interest rate of 5 percent per month that remains stable and affordable.

\section{Model Specification: Methodology}

We follow a quantitative and qualitative research methodology. A multivariate logistic regression model was fitted to the data to identify the factors that affect the NPL behaviour on Qmobile users in Ecuador.

Logistic regression models are commonly used to study effects of predictor variables on a categorical one, usually with binary outcomes, such as the present case where the variable of interest is whether a Qmobile user incurs in NPL. When there are multiple predictors (e.g. age, gender, accumulated savings...) that are hypothesized to influence the outcome, the model is referred to as a multivariable 
logistic regression model. Logistic regression is more adequate than other techniques because it only assumes a binomial distribution for the prediction error, as well as the conditional mean of the binary outcome. Furthermore, logistic regression does not assume a multivariate normal distribution for the independent variables as, for example, discriminant analysis does. For a more extended explanation on logistic regression see, for example, Hosmer et al. (2013).

All calculations were carried out in $\mathrm{R}$ ( $\mathrm{R}$ Core Team 2021), version 3.6.3 running on Xubuntu 20.04.

Our results were contrasted and contextualized with Savinco managers through various interviews, discussions and meetings to help us gain a deeper understanding of the results and correct the possible biases from unobserved individual situation.

\section{Results}

The current Qmobile users are organized in 409 active savings groups, with other 76 groups no longer active. The group life changes from three to 64 months, with the median group life being 24 months. The groups currently contain from 9 up to 88 members, with a median size of 20 , and the median female percentage is currently $69.23 \%$, with a variation from 33 to $100 \%$. Finally, current group capital ranges from $\$ 350$ to $\$ 88,070$, with a median value of $\$ 6450$. The descriptives of these group variables are included in Table 3.

Table 3 Group descriptives

\begin{tabular}{llcccr}
\hline & Min & \multicolumn{1}{l}{ Mean } & Median & Max & \multicolumn{1}{l}{ SD } \\
\hline Z1. Current capital & $\$ 350$ & $\$ 9865.00$ & $\$ 6450.00$ & $\$ 88,070$ & $\$ 11,372.93$ \\
Z2. Initial capital & $\$ 30$ & $\$ 314.80$ & $\$ 180.00$ & $\$ 18,335$ & $\$ 1043.89$ \\
Z3. Current female percentage & 33 & 69.65 & 69.23 & 100 & 0.12 \\
Z4. Initial female percentage & 0 & 68.86 & 68.75 & 100 & 0.16 \\
Z5. Group life (months) & 3 & 26.5 & 24.0 & 64 & 17.35 \\
Z6. Current members & 9 & 27.44 & 24.00 & 88 & 12.60 \\
Z7. Initial members & 0 & 16.63 & 15.00 & 56 & 6.82 \\
\hline
\end{tabular}

Table 4 User descriptives by NPL behaviour

\begin{tabular}{llrrrrr}
\hline & NPL behaviour & Min & Mean & Median & Max & \multicolumn{1}{l}{ SD } \\
\hline $\begin{array}{l}\text { X6. Average loan term } \\
\text { (months) }\end{array}$ & NPL $=0$ & 1.00 & 5.55 & 4.75 & 60.00 & 3.55 \\
X7. Average loan & NPL $=1$ & 1.00 & 7.26 & 6.00 & 52.00 & 5.25 \\
& NPL $=0$ & $\$ 5.00$ & $\$ 344.50$ & $\$ 250.00$ & $\$ 6573.30$ & $\$ 354.39$ \\
X8. Total received amount & NPL $=1$ & $\$ 44.78$ & $\$ 421.30$ & $\$ 302.33$ & $\$ 4062.50$ & $\$ 374.48$ \\
& NPL $=0$ & $\$ 5.00$ & $\$ 2032.00$ & $\$ 1174.00$ & $\$ 72,233.00$ & $\$ 2837.39$ \\
X9. Accumulated savings & NPL $=1$ & $\$ 94.00$ & $\$ 2841.40$ & $\$ 2056.00$ & $\$ 35,048.00$ & $\$ 2913.79$ \\
& NPL $=0$ & $\$ 0.00$ & $\$ 342.90$ & $\$ 235.00$ & $\$ 9430.00$ & $\$ 411.19$ \\
& NPL $=1$ & $\$ 0.00$ & $\$ 336.90$ & $\$ 267.50$ & $\$ 2130.00$ & $\$ 259.88$ \\
\hline
\end{tabular}


Table 5 Frequencies and percentages of user characteristics

\begin{tabular}{|c|c|c|c|c|c|}
\hline Variable & $\begin{array}{l}\text { Value } \\
\text { All }\end{array}$ & $\begin{array}{l}\text { NPL=0 (\%) } \\
6875\end{array}$ & $\begin{array}{l}\text { NPL = 1 (\%) } \\
378\end{array}$ & $\begin{array}{l}\text { Total }(\%) \\
7253\end{array}$ & $\begin{array}{l}\text { NPL rate }(\%) \\
5.21\end{array}$ \\
\hline \multirow[t]{2}{*}{ X1. Gender } & Female & 4885 (71.05) & $247(65.34)$ & $5132(70.76)$ & 4.81 \\
\hline & Male & $1990(28.95)$ & $378(34.66)$ & $2121(29.24)$ & 6.18 \\
\hline \multirow[t]{2}{*}{ X2. Rural } & Yes & $2911(42.34)$ & $131(34.66)$ & 3042 (41.94) & 4.31 \\
\hline & No & $3964(57.66)$ & $247(65.34)$ & $4211(58.05)$ & 5.87 \\
\hline \multirow[t]{7}{*}{ X3. Received loans } & $\leq 1$ & $902(13.12)$ & $17(4.50)$ & $919(12.67)$ & 1.85 \\
\hline & $2-5$ & $3355(48.80)$ & $163(43.12)$ & $3518(48.50)$ & 4.63 \\
\hline & $6-10$ & $1718(24.99)$ & $121(32.01)$ & $1839(25.36)$ & 6.58 \\
\hline & $11-20$ & $792(11.52)$ & $62(16.40)$ & $854(11.7)$ & 7.26 \\
\hline & $21-30$ & $90(1.31)$ & $8(2.12)$ & $98(1.35)$ & 8.16 \\
\hline & $30-40$ & $13(0.19)$ & $7(1.85)$ & $20(0.28)$ & 35.00 \\
\hline & $>40$ & $5(0.07)$ & $0(0.00)$ & $5(0.07)$ & 0.00 \\
\hline \multirow[t]{6}{*}{ X4. Seniority (months) } & $\leq 12$ & $2696(39.21)$ & $56(14.81)$ & $2752(37.94)$ & 2.03 \\
\hline & $25-24$ & $1834(26.68)$ & $83(21.96)$ & 1917 (26.43) & 4.33 \\
\hline & $25-36$ & $1178(17.13)$ & $69(18.25)$ & 1247 (17.19) & 5.53 \\
\hline & $37-48$ & 768 (11.17) & $66(17.46)$ & $834(11.50)$ & 7.91 \\
\hline & $49-60$ & $228(3.32)$ & $69(18.25)$ & 297 (4.09) & 23.23 \\
\hline & $>60$ & $171(2.49)$ & $35(9.26)$ & $206(2.84)$ & 16.99 \\
\hline \multirow[t]{6}{*}{ X5. Age (years) } & $\leq 18$ & $103(1.50)$ & $4(1.06)$ & $107(1.48)$ & 3.74 \\
\hline & $18-25$ & $1016(14.78)$ & $53(14.02)$ & $1069(14.74)$ & 4.96 \\
\hline & $25-40$ & $2481(36.09)$ & $137(36.24)$ & $2618(36.10)$ & 5.23 \\
\hline & $40-55$ & 2108 (30.9) & $107(28.31)$ & 2215 (30.54) & 4.83 \\
\hline & $55-70$ & $968(14.08)$ & $55(14.55)$ & $1,023(14.10)$ & 5.38 \\
\hline & $>70$ & 199 (2.89) & $22(5.82)$ & $221(3.05)$ & 9.95 \\
\hline
\end{tabular}

Descriptives by NPL behaviour for the individual user continuous variables are presented in Table 4. It is interesting to observe how the maximum values for all four variables are much higher than for those users with no NPL past behaviour $(\mathrm{NPL}=0)$. However, the median is in all four cases smaller than for those users with NPL behaviour (NPL=1), as it is the mean, except for the accumulated savings.

Finally, for a complete overview of the user's independent variables that are included in the model, a summary of the frequencies, percentages and default rates of the qualitative and discrete variables is presented in Table 5. Default rate is calculated by dividing the number of members that have defaulted $(\mathrm{NPL}=1)$ by total members.

Out of 7251 analysed users, there are only 378 with non-performing loans, a mere $5.21 \%$, hence the NPL rate is quite small among the Qmobile users that had ever borrowed money. Furthermore, by examining Table 5 it appears that as age increases, the proportion of individuals with NPL increases. Something similar seems to happen both with seniority and with the number of received loans. Finally, 
Table 6 Post-estimation VIF test

\begin{tabular}{ll}
\hline Variables & VIF \\
\hline X1. Gender & 1.111531 \\
X2. Rural & 1.218682 \\
X3. Received loans & 4.090211 \\
X4. Seniority & 4.764794 \\
X5. Age & 1.079317 \\
X6. Average loans term & 1.841376 \\
X7. Average loan & 3.169891 \\
X8. Total received amount & 4.565030 \\
X9. Accumulated savings & 2.447600 \\
Z1. Current capital & 4.941217 \\
Z2. Initial capital & 1.321156 \\
Z3. Current female percent & 2.202914 \\
Z4. Initial females percent & 2.088687 \\
Z5. Group life & 3.957181 \\
Z6. Current members & 3.863196 \\
Z7. Initial members & 1.542326 \\
\hline
\end{tabular}

it also appears that being a male and not belonging to a rural area increases slightly the probability of NPL behaviour.

The degree of multicollinearity among the explanatory variables has been tested using variance inflation factor (VIF) test and the post-estimation model results presented in Table 6 show that the value of variance inflation factor ranges between 1.08 and 4.94 (all of them below 5), implying that the data have no multicollinearity problems among explanatory variables used in the multivariate logistic regression model (James et al. 2013).

Maximum likelihood estimates of the parameters in the logistic regression model characterizing the NPL behaviour of Qmobile users are presented in Table 7. It must be noted that the estimated coefficients do not directly indicate the effect of change in our explanatory variable of NPL behaviour. Those estimated coefficients indicate the effect of each individual explanatory variable on the probability of the NPL behaviour occurring. Particularly, a positive (negative) coefficient means that the log of odds $\{\ln$ [Probability/(1 - Probability)] $\}$ increases (decreases) as the corresponding variable increases.

The result of the Hosmer-Lemeshow test (chi square $=7253$; $\mathrm{df}=8 ; p<2.2 \mathrm{e}-16$ ) indicates no evidence of poor fit. Hence, it is confirmed that the model fits the data. The estimated logit model is given by the following expression:

$$
\begin{aligned}
\operatorname{Logit}\{\mathrm{NPL}= & 1 / \text { independent variables }\}=-3.85081+0.21182 X 1-0.13206 X 2 \\
& -0.02789 X 3+0.04884 X 4+0.00238 X 5 \\
& +0.04237 X 6+0.00071 X 7+0.00008 X 8-0.00282 X 9 \\
& -0.00003 Z 1-0.00016 Z 2+0.06146 Z 3-0.91763 Z 4 \\
& +0.03200 Z 5-0.02823 Z 6+0.03736 Z 7
\end{aligned}
$$


Table 7 Parameters in the logistic regression model

\begin{tabular}{lrlrlll}
\hline & \multicolumn{1}{c}{ Estimate } & SE & z value & $\operatorname{Pr}(>|\mathrm{z}|)$ & & Odds ratio \\
\hline (Intercept) & -3.85081 & 0.44602 & -8.634 & $<2 \mathrm{e}-16$ & $* * *$ & 0.0213 \\
X1. Gender [T. male] & 0.21182 & 0.12571 & 1.685 & 0.09199 & $*$ & 1.2359 \\
X2. Rural [T. yes] & -0.13206 & 0.12914 & -1.023 & 0.30649 & & 0.8763 \\
X3. Received loans & -0.02789 & 0.01922 & -1.451 & 0.14680 & & 0.9725 \\
X4. Seniority & 0.04884 & 0.00676 & 7.218 & $5.26 \mathrm{e}-13$ & $* * *$ & 1.0500 \\
X5. Age & 0.00238 & 0.00396 & 0.602 & 0.54699 & & 1.0024 \\
X6. Average loans term & 0.04237 & 0.01689 & 2.507 & 0.01217 & $* *$ & 1.0433 \\
X7. Average loan & 0.00071 & 0.00032 & 2.221 & 0.02636 & $* *$ & 1.0007 \\
X8. Total received amount & 0.00008 & 0.00004 & 1.794 & 0.07283 & $*$ & 1.0001 \\
X9. Accumulated savings & -0.00282 & 0.00041 & -6.776 & $1.24 \mathrm{e}-11$ & $* * *$ & 0.9972 \\
Z1. Current capital & -0.00003 & 0.00001 & -2.023 & 0.04304 & $* *$ & 0.9999 \\
Z2. Initial capital & -0.00016 & 0.00024 & -0.657 & 0.51107 & & 0.9998 \\
Z3. Current female percent & 0.06146 & 0.65754 & 0.093 & 0.92553 & & 1.0634 \\
Z4. Initial females percent & -0.91763 & 0.48893 & -1.877 & 0.06054 & $*$ & 0.3995 \\
Z5. Group life & 0.03200 & 0.00604 & 5.295 & $1.19 \mathrm{e}-07$ & $* * *$ & 1.0325 \\
Z6. Current members & -0.02823 & 0.00846 & -3.335 & 0.00085 & $* * *$ & 0.9722 \\
Z7. Initial members & 0.03736 & 0.00813 & 4.595 & $4.32 \mathrm{e}-06$ & $* * *$ & 1.0381 \\
\hline
\end{tabular}

Signif. codes: ${ }^{*} p<0.1,{ }^{* *} p<0.05,{ }^{* * *} p<0.01$

Overall, most of the explanatory variables had expected signs. Particularly, gender, seniority (individual), total received amount, average loan, average loan term, group life and initial members had a consistently positive and significant effect (at $10 \%$ level) on NPL behaviour. Accumulated savings, current capital (group), number of current members (group) and initial female's percentage (group) have also a significant effect on defaulting, but negative, meaning the higher the value of the variables, the lower the probability of NPL behaviour. However, neither age nor the number of received loans, rural, group initial capital or the current female percentage (group) have any significative effect on NPL behaviour.

It is of special importance gender (male) and initial female's percentage because of their odds ratio deviation from 1. Concretely, the odds of a male incurring in NPL behaviour are 1.2359 times greater than the odds for females. Additionally, for each point increase on the initial percentage of female in the group, the odds of the members of that group incurring in NPL behaviour decrease from 1 to 0.3995 .

\section{Findings Discussion}

In our research, we have analysed the relative importance of several factors on the probability of default using a sample of 7251 active users of the "Saving and Leaning" Program developed in Ecuador by SAVINCO from 2014 to 2020. All these 
users had been with the organization for at least three months. In this section, we will discuss our findings.

SGs are being used in many parts of the world as a strategy to give access to financial services to the population in the bottom of the pyramid with the final objective of reducing poverty. Nevertheless, the inherent risk attached to these small loans is a major concern for MFIs and NPOs. Understanding SGs member's characteristics could play an important role in reducing loan default rates.

The potential factors determining microcredit default have been analysed in line with Adongo and Stock (2005); Field et al. (2010); Kodongo and Kendi (2013) and Muthoni (2016). Most of these studies have been performed for specific countries and years limiting the generalizations to other countries or situations. Nevertheless, there are some borrower's characteristics examined in the present research that are significant in most of these studies. These factors include gender, age, numbers of loans, loan amount and repayment period.

It is very interesting to observe that the average default rate in our sample is $5.21 \%$ which is relatively low in comparison with Ecuador default rate of Microcredits issued by Cooperativas (Savings and Loan Associations) which was $5.88 \%$ in September 2019, and much lower than public banks with a microcredit default rate of 7.76\% (Ocaña 2018). A possible explanation for this fact might be that traditional banks have a higher percentage of individual loans that are associated with higher default rates than group lending (Kodongo and Kendi 2013; Mokhtar et al. 2009) and that financial education improves savings and the responsible use of the loan.

The significant positive sign on "Gender (Male)" is consistent with previous authors that indicate that the probability of having problems in loan repayment is higher for males than for females. A higher percentage of female's clients in MFIs is associated with a lower portfolio risk, fewer write-offs and fewer provisions (Adusei 2013; Banerjee et al. 2015; D’Espallier et al. 2011; Giné and Karlan 2014). Although the gender variable was significant only at a $10 \%$ level, the odds of a male incurring default are 1.24 times greater than the odds for females.

Although "Age" is not statistically significant in our model, the NPL rate of customers over 55 years is higher than the average NPL rate (see Table 5). These results are not consistent with the research carried out by Mokhtar et al. (2009) and Bhatt and Tang (2002). Both suggest that older borrowers have more experience and would be more responsible in repaying their loans than younger borrowers.

"Seniority" and "Group Life" coefficients are both positive and significant at a 0.1 level. Savinco managers pointed out that the "Seniority" result might be logical, as they have observed that users tend to be less risk adverse after years being part of a savings group and may become over-indebted. Consequently, a similar consequence might happen with "Group Life". We recommend that before granting a new loan, records of borrowers' financial obligations in other institutions should be required.

Accumulated savings is inversely related to NPL, and significant at a 0.1 level. Accumulated savings represents individual savings, therefore it is expected that borrowers with a high level of savings have less of a chance of default, since it would be against their own interest.

Furthermore, results suggest that Average loan and Average loan term are significant factors (both at 5\% level) influencing directly the chance of default. This result 
is opposite to authors such as Mokhtar et al. (2009) who defend that the lower the loan amount, the higher the chance of default since low loan amounts are mostly extended to first business beginners who lack experience and larger amounts are mostly granted to more experienced borrowers. They also suggest that a weekly loan repayment schedule posed problems for borrowers who generate a lower revenue cycle and suggested that MFIs should consider lowering the weekly repayment amount and providing a longer duration of payments in response. Furthermore, Kodongo and Kendi (2013) suggest that larger loan amounts are associated with fewer incidents of delinquency. Moreover, Savinco managers explained that the average loan term is not an important factor in client delinquency but the size of the regular payments, and suggest that regular instalments should not be higher that a $30 \%$ of their salary. Savinco managers affirm that the problem is not the loan term but the regular repayment capacity.

Initial and Current Members are both significant (at $0.1 \%$ ) but in opposite directions. Initial Members is positively related to default, while Current Members is inversely related to default. SAVINCO managers explain that large initial members relationship with higher default rates might be due to the fact that members do not know each other well enough and there is not a clear leader and group procedures, in line with Conning (2005) that suggests that broad initial groups may not be able to enforce the cooperative agreements necessary for group repayment. On the contrary, the result that Current Members is inversely related to default is consistent with the literature that suggest that after some time, larger groups know each other well and can take greater advantage of local information reducing adverse selection and moral hazard (Ahlin 2015). It is also well known that diversification can reduce risk and sufficiently large groups can attain first-best lending.

Finally, SAVINCO managers are concerned about financial training and are implementing more active leanings methodologies using the mobile platform and quality control measures. They stated that it is important to observe the beneficiaries' behaviour in relation to debt recurrence to prevent them from over-indebtedness. As hypothesized, given the financial education provided in the regular repayment meetings, the higher number of attended sessions the better prepared microcredit beneficiaries are to make appropriate decisions regarding loan size and repayment period.

\section{Conclusions}

Savings groups programs have expanded rapidly all around the world providing an alternative way of financing excluded population. Although there is abundant literature about microfinance impact, outreach and sustainability (Gutierrez-Nieto and Serrano-Cinca 2019; Van Rooyen et al. 2012; Hermes and Lensink 2009), there is scarce research about the determinants of loan-repayment in microcredit savings groups. The purpose of this research was to identify the savings group members' characteristics that minimize default risk. We have analysed a sample of more than 400 SGs and 7253 active users of the "Saving and Learning" program, developed by 
SAVINCO in Ecuador from 2014 to 2020. The information was extracted from the cloud-mobile App Qmobile that records all group-lending transactions.

We have used a binary logistic regression model to identify the factors that affect the non-performing loan or default behaviour among microcredit borrowers from savings groups in Ecuador, which led to interesting findings. Overall, most of the explanatory variables had expected behaviours. Particularly, gender, seniority, total received amount, average loan, average loan term, group life and initial members had a positive and significant effect on default. Accumulated savings, group current capital, number of current members and initial females' percentage have also a significant effect but inverse, meaning the higher value of the variables, the lower the probability of default. However, neither age nor the number of received loans, rural area, group initial capital or current female percentage has any significant effect on NPL behaviour.

As a result, our first conclusion is the necessity of these groups to control overindebtedness. We recommend a break period between loans, since after years of continuously borrowing SGs members could tend to be less risk adverse. In addition, before granting a new loan records of borrowers' financial obligations at other institutions should be required. Regarding the loan size and term, we consider that the important factor is the regular repayment instalments. They should not be more than $30 \%$ of their regular income as SAVINCO managers suggested. In relation to group size, too broad initial groups could be a factor of concern since joint liability might not work well if members do not know each other or do not have strong family ties.

Furthermore, the use of technology in SGs should be promoted. Although the main purpose of the platform was to help group members efficiently manage their monthly meetings, the online data allow users and managers to perform a continuous follow-up and quality control of the program. In addition, an App is a perfect channel to provide financial education to SGs members. The challenge is to generate long-term saving habits and management skills that will allow users to improve their financial health and consequently improve their life conditions.

The contributions of this paper could be classified in contributions for practitioners, academics and development institutions. For practitioners, based on the results of this study, we have identified relevant factors that can affect SGs default rates. For academics, the rich information provided by the Mobile App could be a starting point for further quantitative research once the financial education App is designed. Finally, for international development institutions, we suggest that all the actors involved such as the government, NPOs and MFIs should work together to provide the necessary framework to promote the use of technologies for financial inclusion and education. Cooperation among the different actors is the only way to achieve economic growth in a sustainable and inclusive way.

No study is without limitations. First of all, the generalizability of our findings might be restricted by our focus on one saving group platform in Ecuador. These results should, of course, be interpreted with caution, as they may be idiosyncratic of the period and region. A second potential limitation is that the information used was not complete, additional group members qualitative and socio-economic information will be needed to complete the borrower profile in order to produce comprehensive 
credit scoring. Last but not least, the information was extracted before the COVID19 pandemic that has greatly affected all levels of society worldwide.

Finally, the present results legitimize the authors to continue exploring on this area. There is a need for more research that can assist both lenders and borrowers achieve jointly economic growth in a sustainable and inclusive way. Future research lines include the design of a complete borrower's profile and credit scoring, together with other variables such as inflation, weather conditions, political, financial or health crisis (COVID-19) impact on savings groups programs defaults.

Acknowledgements The authors gratefully acknowledge Savinco Social Finance (www.Savinco.org) and Inversión \& Cooperación for the access to their Q-Mobile platform in Ecuador and for the valuable fieldwork input and their constant support. All personal information that would allow the identification of any person has been removed.

\section{References}

Adongo, J. and Stock, C. 2005. Factors influencing the financial sustainability of selected microfinance institutions in Namibia. Namibian Economic Policy Research Unit, Windhoek.

Adusei, M. 2013. Determinants of credit union savings in Ghana. Journal of International Development 25: $22-30$.

Ahlin, C. 2015. The role of group size in-group lending. Journal of Development Economics 115: $140-155$.

Ahlin, C., and B.M. Waters. 2014. Dynamic lending under adverse selection with limited borrower commitment: Can it outperform group lending? Journal of Development Economics 121: $237-257$.

Al-Azzam, M., R.C. Hil, and S. Sarangi. 2012. Repayment performance in group lending: Evidence from Jordan. Journal of Development Economics 97: 404-414.

Allen, B. 2018. State of practice: Savings Groups and the dynamics of inclusion. The SEEP network. https://seepnetwork.org/files/galleries/SEEP_State-of-Practice_Savings-Groups-and-the-Dynam ics-of-Inclusion_20180925.pdf

Anthony, D., and C. Horne. 2003. Gender and cooperation: Explaining loan repayment in micro-credit groups. Social Psychology Quarterly 66 (3): 293-302.

Ardener, S. 1964. The comparative study of rotating credit associations. The Journal of the Royal Anthropological Institute of Great Britain and Ireland 94 (2): 201-229.

Arellano, A., N. Cámara, and D. Mejía. 2019. Disentangling vulnerability through consumer behavior: The role of financial health. BBVA research working paper $N^{o}$ 10/11. https://www.bbvar esearch.com/wp-content/uploads/2019/08/WP_Financial_Health_Vulnerability_0812.pdf

Armendáriz, B., and J. Morduch. 2005. The economics of microfinance. Cambridge, MA: MIT Press.

Ashraf, B.N. 2020. Stock markets' reaction to COVID-19: Cases or fatalities? Research in International Business and Finance 54: 101249. https://doi.org/10.1016/j.ribaf.2020.101249.

Ashraf, B.N., D. Karlan, and W. Yin. 2006. Tying Odysseus to the mast: Evidence from a commitment savings product in the Philippines. Quarterly Journal of Economics 121 (2): 635-672.

ASOMIF Ecuador. 2019. "Construyendo el futuro de la inclusión financiera en ecuador. Memoria diciembre 2019”. https://asomifecuador.com/wp-content/uploads/2019/12/memoria_alianza_ 2019.pdf

Attanasio, O., B. Augsburg, R. De Haas, E. Fitzsimons and H. Harmgart. 2013. Group lending or individual lending? Evidence from a randomized field experiment in rural Mongolia. Center discussion paper series no. 2013-074, SSRN. https://doi.org/10.2139/ssrn.2365432.

Baland, J.M., L. Gangadharan, P. Maitra and Somanathan. 2017. Repayment and exclusion in a microfinance experiment. Journal of Economic Behaviour and Organization, 137(C), 176-190.

Bali, S.R., and A. Varghese. 2013. Delivery mechanisms and impact of microfinance training in Indian self- help groups. Journal of International Development 25: 11-21. 
Ballem, A., A.M. Ghiyazuddin, and N.A. Venkata. 2012. Why do people not join or drop out of SHGs?. Microsave market-led-solutions for financial services. https:/www.findevgateway.org/sites/default/ files/publications/files/mfg-en-paper-why-do-people-not-join-or-drop-out-of-shgs-may-2012.pdf

Banerjee, A., E. Duflo, R. Glennerster, and C. Kinnan. 2015. The miracle of microfinance? Evidence from a randomized evaluation. American Economic Journal: Applied Economics 7 (1): 22-53.

Bateman, M., and H. Chang. 2009. The microfinance illusion. World Economic Review. https://doi.org/ $10.2139 /$ ssrn.2385174.

Beg, K., and H.A. Bashir. 2017. An empirical analysis of factors affecting the loan repayment performance of microfinance institutions. Pacific Business Review International 10 (2): 144-153.

Benartzi, S., and R. Thaler. 2004. Save more tomorrow: Using behavioural economics to increase employee savings. Journal of Political Economy 112 (2): 5164-5187.

Berge, L.I.O., K. Bjorvatn, K.S. Juniwatya, and B. Tungoddena. 2012. Business training in Tanzania: From research-driven experiment to local implementation. Journal of African Economies 21 (5): $808-827$.

Bhatt, N., and S.-Y. Tang. 2002. Determinants of repayment in microcredit: Evidence from programs in the United States. International Journal of Urban and Regional Research 26 (2): 360-376.

Bicciato, F., Foschi, L., Bottaro, E. and Ivardi Ganapini, F. 2020. Microfinanzas en países pequeños de América Latina: Bolivia, Ecuador y El Salvador. CEPAL SERIE Desarrollo productivo, N 121. https://www.cepal.org/sites/default/files/publication/files/4506/S022121_es.pdf

Bouman, F.J.A. 1983. Indigenous savings and credit societies in the developing world. Washington: World Bank.

Churchill, C.F. 2004. La microfinance est-elle une priorité pour les pauvres? Comprende la demande de services financiers de gestion des risques. ADA Dialogue 33: 11-30.

Ciravegna, D. 2006. The role of microcredit in modern economy: the case of Italy. Flacso working paper, Costa Rica.

Conning, J. 2005. Monitoring by peers or by delegates? Joint liability loans and moral hazard. Economics working paper archive at Hunter College 407, Hunter College Department of Economics. https:// ideas.repec.org/p/htr/hcecon/407.html.

Cuadra, G., and H. Sapriza. 2008. Sovereign default, interest rates and political uncertainty in emerging markets. Journal of International Economics 76 (1): 78-88. https://doi.org/10.1016/j.jinteco.2008. 05.001 .

Cull, R., A. Demirgüc-Kunt, and J. Morduch. 2018. The microfinance business model: Enduring subsidy and modest profit. The World Bank Economic Review 32 (2): 221-224.

D’Espallier, B., R. Mersland, and I. Guérin. 2011. Women and repayment in microfinance: A global analysis. World Development 39 (5): 758-772.

de Mel, S., D. Mckenzie, and C. Woodruff. 2009. Are women more credit constrained? Experimental evidence on gender and microenterprise returns. American Economic Journal: Applied Economics 1 (3): 1-32.

de Mel, S., D. McKenzie, and C. Woodruff. 2014. Business training and female enterprise start-up, growth, and dynamics: Experimental evidence from Sri Lanka. Journal of Development Economics 106: 199-210.

de Quidt, J., T. Fetzer, and M. Ghatak. 2016. Group lending without joint liability. Journal of Development Economics 121: 217-236.

Deb, A., and Kubzansky, M. 2012. Bridging the gap: The business case for financial capability. Citi Foundation and GIIN

Dellien, H., J. Burnett, A. Gincherman, and E. Lynch. 2005. Product diversification in microfinance: Introducing individual lending. Women's. New York: World Banking Report.

Ditcher, T. 2007. Hype and hope: The worrisome state of the microcredit movement. Legal City Legal Magazine 26.

Demirgüc-Kunt, A., L. Klapper, D. Singer, S. Ansar, and J. Hess. 2018. The Global Findex Database 2017: Measuring financial inclusion and the fintech revolution. The World Bank. https://doi.org/ 10.1596/978-1-4648-1259-0

Drexler, A., G. Fischer, and A. Schoar. 2014. Keeping it simple: Financial literacy and rules of thumb. American Economic Journal: Applied Economics 6: 1-31.

Duflo, E. 2012. Women empowerment and economic development. Journal of Economic Literature 50 (4): 1051-1079. 
Duflo, E., W. Gale, J. Liebman, P. Orszag, and E. Saez. 2006. Saving Incentives for low- and middleincome families: Evidence from a field experiment with Hand R block. Quarterly Journal of Economics 121 (4): 1311-1346.

Eckel, C.C., and P.J. Grossman. 1998. Are women less selfish than men? Evidence from dictator experiments. The Economic Journal 108 (448): 726-735.

Eckel, C.C., and P.J. Grossman. 2002. Sex differences and statistical stereotyping in attitudes towards financial risks. Evolution and Human Behavior 23 (4): 281-295.

Fafchamps, M., McKenzie, D., Quinn, S., and Woodruff, C. 2011. When is capital enough to get female microenterprises growing? Evidence from a randomized experiment in Ghana. Policy Research Working Papers. World Bank. https://doi.org/10.1596/1813-9450-5706

Feigenberg, B., R. Pande, N. Rigol, and S. Sarkar. 2014. Do group dynamics influence social capital and female empowerment? Experimental evidence from microfinance. Journal of Policy Analysis and Management 33 (4): 932-949.

Field, E., and R. Pande. 2008. Repayment frequency and default in microfinance: Evidence from India. Journal of the European Economic Association 6: 501-509.

Field, E., R. Pande, and J. Papp. 2010. Does microfinance repayment flexibility affect entrepreneurial behavior and loan default?. Microfinance Gateway, 6. https://www.moodys.com/microsites/miic2 010/presentationfiles/Field.pdf.

FMBBVA - Fundación Microfinanzas BBVA. 2019. Informe de desempeño social 2019. www.funda cionmicrofinanzasbbva.org

Gash, M. 2013. Pathways to change: The impact of group participation. In Savings groups at the frontier, ed. C. Nelson, 101-125. Rugby: Practical Action.

Gash, M. 2017. Understanding the impact of savings groups. The SEEP Network. https://seepnetwork. org/files/galleries/Understanding.pdf.

Ghatak, M. 2000. Screening by the company you keep: Joint liability lending and the peer selection effect. The Economic Journal 10 (465): 601-631.

GSMA. 2019. Mobile industry impact report: Sustainable development goals. https://www.gsma.com/ betterfuture/2019sdgimpactreport/wp-content/uploads/2019/09/SDG_Report_2019_ExecS ummary_Web_Singles.pdf

Ghosh, P., and D. Ray. 2016. Information and enforcement in informal credit markets. Economica 83 (329): 59-90. https://doi.org/10.1111/ecca.12169.

Gigante, S. 2017. Tanda, hui, or ayuuto? The money pool way. MassMutual Blog. https://blog.massm utual.com/post/money-pools

Giné, X., and D.S. Karlan. 2014. Group versus individual liability: Short- and long-term evidence from Philippine microcredit lending groups. Journal of Development Economics 107: 65-83.

Global Microscope. 2019. The enabling environment for Financial Inclusion and the expansion of digital financial services. E.I.U-Economist Intelligence Unit New York, NY: EIU https://www.centerforf inancialinclusion.org/global-microscope-2019

Golden, L.L., M.L. Wang, and C.H. Yang. 2007. Handling weather related risks through the financial markets: Considerations of credit risk, basis risk, and hedging. Journal of Risk and Insurance 74 (2): 319-346. https://doi.org/10.1111/j.1539-6975.2007.00215.x.

Gugherty, M.K. 2007. You can't save alone: Commitment in rotating savings and credit associations in Kenya. Economic Development and Cultural Change 55: 251-282.

Gutierrez-Nieto, B., and C. Serrano-Cinca. 2019. 20 years of research in microfinance: An information management approach. International Journal of Information Management 47: 183-197.

Haldar, A., and J.E. Stiglitz. 2016. Group lending, joint liability, and social capital: Insights from the Indian Microfinance Crisis. Politics and Society 44 (4): 459-497.

Hermes, N., and R. Lensink. 2009. Microfinance: Its impact, outreach and sustainability. World Development 39: 875-881.

Hosmer, D.W., Jr., S. Lemeshow, and R.X. Sturdivant. 2013. Applied logistic regression, 3rd ed. Hoboken, NJ: Wiley.

Hulme, D., and P. Mosley. 1996. Finance against poverty. London: Routledge.

Husain, Z., D. Mukherjee, and M. Dutta. 2010. Self-help groups and empowerment of women: Selfselection or actual benefits? Journal of International Development 26 (4): 422-437.

James, G., D. Witten, T. Hastie, and R. Tibshirani. 2013. An Introduction to Statistical Learning: With Applications in R. New York: Springer.

Karlan, D. 2007. Social connections and group banking. The Economic Journal 117 (517): F52-F84. 
Karlan, D., A.L. Ratan, and J. Zinman. 2014. Savings by and for the poor: A research review and agenda. Review of Income and Wealth V60 (1): 36-78.

Karlan, D., and M. Valdivia. 2011. Impact of business training on microfinance clients and institutions. Review of Economics and Statistics 93 (2): 510-527.

Karlan, D.S., B. Savonitto, B. Thuysbaert, and C.R. Udry. 2017. Impact of savings groups on the lives of the poor. Proceedings of the National Academy of Sciences 114: 3079-3084.

Karnani, A. 2011. Fighting poverty together: Rethinking strategies for business, governments, and civil society to reduce poverty. New York: Palgrave Macmillan.

Karnani, A. 2017. The roles of the private and public sectors in poverty reduction. Journal of Marketing and Management 33 (118): 1585-1592.

Kirkpatrick, C., and M. Maimbo. 2002. The implications of the evolving microfinance agenda for regulatory and supervisory policy. Development Policy Review 20 (3): 293-304.

Kodongo, O., and L.G. Kendi. 2013. Individual lending versus group lending: An evaluation with Kenya's microfinance data. Review of Development Finance 3 (2): 99-108.

Le-Polain, M., O. Sterck, and M. Nyssens. 2018. Interest rates in savings groups: Thrift or threat? World Development 101: 162-172.

López-Sánchez, P., E. Urquía-Grande, C. del Campo, and M.J. Rivero-Menendez. 2020. The importance of accounting for micro-credit beneficiaries in developing countries. Enterprise Development and Microfinance 31 (4): 268-283.

Mader, P. 2013. Rise and fall of microfinance in India: The Andhra Pradesh crisis in perspective. Strategic Change 22 (1-2): 47-66. https://doi.org/10.1002/jsc. 1921.

Mader, P. 2017. Contesting financial inclusion. Development and Change 49 (2): 461-483.

Madestam, A. 2014. Informal finance: A theory of moneylenders. Journal of Development Economics 107: $157-174$.

Maity, S. 2019. Financial inclusion and multidimensional poverty reduction through self-help-group-led microfinance: Evidence from Bodoland, Assam, India. Enterprise Development and Microfinance 30 (3): 152-173.

Maria, L. 2009. Group lending versus individual lending in microfinance. No. 299. SFB/TR 15 Discussion Paper, University of Munich.

Marr, A. 2004. A challenge to the orthodoxy concerning microfinance and poverty reduction. Journal of Microfinance 5 (2): 1-35.

Microfinance Barometer. 2018. http://www.convergences.org/wp-content/uploads/2018/09/BMF_2018_ EN_VFINALE.pdf.

Mirpourian, S., A. Caragliu, G. Di Maio, P. Landoni, and E. Rusinà. 2016. Determinants of loan repayment performance among borrowers of microfinance institutions: Evidence from India. World Development Perspectives 1: 49-52. https://doi.org/10.1016/j.wdp.2016.06.002.

Mokhtar, S.T., Nartea, G., and Gan, C. 2009. Determinant of Microcredit Loan Repayment Problem among Microfinance Borrowers in Malaysia. http://www.microfinancegateway.org/gm/document1.9.57549/

Mookherjee, D., and A. Motta. 2016. A theory of interactions between MFIs and informal lenders. Journal of Development Economics 121: 191-200.

Morris, M.H., S.C. Santos, and X. Neumeyer. 2018. Poverty and entrepreneurship in developed economies. Cheltemham: Edward Elgar Publishing.

Muthoni, P. 2016. Assessing borrower's and business' factors causing microcredit default in Kenya: A comparative analysis of microfinance institutions and financial intermediaries. Journal of Education and Practice 7: 97-118.

Navajas, S., M. Schreiner, R.L. Meyer, C. Gonzalez-Vega, and J. Rodríguez. 2000. Microcredit and the poorest of the poor: Theory and evidence from Bolivia. World Development 28 (2): 333-346.

Nelson, C. 2013. Savings groups at the frontier. Uitgever: Practical Action Publishing.

Norell, D. 2001. How to reduce arrears in microfinance institutions. Journal of Microfinance 3: 115-130.

Nzemen, M. 1988. Théorie de la pratique des tontines au Cameroun. Yaoundé: Société de presse et d'éditions du Cameroun.

Ocaña, E. (2018). "Formalización de las Microfinanzas y su impacto en el Desarrollo del Sistema Financiero Ecuatoriano”. Superintendencia de Bancos, Documento de Trabajo No. 2

Ochoa, B., de Salas Lasagabaster, A., and Robredo Núñez, M. 2016. El Nuevo modelo de creación de valor de la banca basado en tecnologías disruptivas. Mindsait, Indra. https://www.minsait.com/es/ actualidad/insights/el-nuevo-modelo-de-creacion-de-valor-de-la-banca-basado-en-las-tecnologias. 
Ontiveros, E., Martín Enriquez, A., and Lopez Sabater. 2014. Microfinanzas y TIC. Experiencias Innovadoras en Latinoamérica. Fundación Telefónica and Analistas Financieros Internacionales (AFI).

Owusu-Manu, D., E.A. Parn, K. Donkor-Hyiaman, D.J. Edwards, and K. Blackhurst. 2016. The relative importance of mortgage pricing determinants in mortgage affordability in Ghana: An ex post attribution. Journal of Engineering Design and Technology 14 (3): 563-579. https://doi.org/10.1108/ JEDT-06-2014-0040.

Pellegrina, L.D. 2011. Microfinance and Investment: A comparison with bank and informal lending. World Development 39 (6): 882-897.

Pitt, M., and S.R. Khandker. 1998. The impact of group-based credit programs on poor households in Bangladesh: Does the gender of participants matter? Journal of Political Economy 106 (5): 958996. https://doi.org/10.1086/250037.

Pole, P., A. Asawa, and D. Shah. 2014. A critical evaluation of the SKS microfinance fiasco. Indian Journal of Finance 8 (6): 7-21. https://doi.org/10.17010/ijf/2014/v8i6/71907.

Pollin, R., and Feffer, J. (2007). "Microcredit: False Hopes and Real Possibilities. Is microcredit the solution to global poverty? Yes and no....". Foreign policy in Focus. https://fpif.org/microcredit_ false_hopes_and_real_possibilities/

Prahalad, C.K., and A.L. Hammond. 2002. Serving the world's poor, profitably. Harvard Business Review 80 (9): 48-57.

Prina, S. 2015. Banking the poor via savings accounts: Evidence from a field experiment. Journal of Development Economics 115: 16-31.

R Core Team. 2021. R: A language and environment for statistical computing. R Foundation for Statistical Computing, Vienna, Austria. https://www.R-project.org/

Raihan, M., and M.J. Uddin. 2018. Creating women's capabilities through microcredit in Bangladesh. Sri Lanka Journal of Social Sciences 41 (2): 111-122. https://doi.org/10.4038/sljss.v41i2.7698.

Reinhart, C., and K. Rogoff. 2010. Growth in a Time of Debt. American Economic Review: Papers and Proceedings 100: 573-578.

SAVINCO. 2020. Savinco Social Finance. www.savingo.org

Savita, S. 2007. Transaction costs in group microcredit in India. Management Decisions 45: 1331-1342.

Shivaprasad, G. 2020. Role of microfinance-Transforming the social conditions of women SHG. Test Engineering and Management 83: 2668-2680.

Umuhire P.G. 2013. Informal finance and formal microfinance: The rationale of their coexistence in the context of urban African financial markets. Presses Universitaires de Louvain.

United Nations. 2015. Transforming our world: The 2030 agenda for sustainable development. https:// sustainabledevelopment.un.org/post2015/transformingourworld/publication.

Urquía-Grande, E., A. Rautiainen, and R. Pérez-Estébanez. 2017. The effectiveness of rural versus urban non-profit organisations in the Democratic Republic of Congo. Third World Quarterly 38 (9): 2129-2142. https://doi.org/10.1080/01436597.2017.1322464.

Van Rooyen, C., R. Stewart, and T. de Wet. 2012. The impact of microfinance in sub-Saharan Africa: A systematic review of the evidence. World Development 40 (11): 49-62.

Vogelgesang, U. 2003. Microfinance in times of crisis: The effects of competition, rising indebtedness, and economic crisis on repayment behaviour. World Development 31 (12): 2085-2114.

Wydick, B., H.K. Hayes, and S.H. Kempf. 2011. Social networks, neighbourhood effects and credit access: Evidence from rural Guatemala. World Development 39 (6): 974-982.

Yunus, M. 2003. Banker to the poor micro-lending and the battle against world poverty. New York: Perseus Books LLC.

Publisher's Note Springer Nature remains neutral with regard to jurisdictional claims in published maps and institutional affiliations.

Pilar López-Sánchez is an Associate Professor of Management and Cost accounting at the faculty of Business \& Administration at Universidad Francisco de Vitoria in Madrid, Spain. She has done teaching and research stances in LaHage, London, Paris and Peru. She graduated in Economics at Universidad Complutense of Madrid, holds a Master degree in Economics and Finance in UCSB (University California Santa Barbara and a Master degree in "The Austrian School of Economics" from the Universidad Rey Juan Carlos, Madrid. Her main research areas are financial inclusion and financial education in 
developing countries. From 2013 to 2020, she was Board member and Financial Director of The Spanish Cancer Association (AECC). Since 2013 she is Editorial Board member of LID, a leading international publishing company. Prior to that, she worked in the financial sector, first in Banco Santander in Madrid and London, and later in a private equity fund, named Saarema de Inversiones in Madrid. During this period, she also occupied a seat on the Boards of directors of some of the companies participated by the fund.

Elena Urquía-Grande holds a Ph.D. in Economics from the Complutense University of Madrid, MBA from the University of Houston (USA). She is tenured as an Associate Professor in the Department of Accounting and Finance, Faculty of Economics and Business, Complutense University of Madrid. She was Vice-dean of International Affairs and Cooperation for Development. She has done several teaching and research stances in Finland, Berlin, Ethiopia, Congo and USA. Research and publication lines: Accounting for Economic Development and Higher Education. She has done several publications in international research journals with impact in JCR and Scimago databases. She is Director of the READEES research project (Research in Economics and Accounting, Europe-Africa for the Development of Emerging Economies towards Sustainability).

Cristina del Campo is a tenured Associate Professor of Decision Sciences and Statistics at the Faculty of Economics and Business at the Universidad Complutense de Madrid (Spain). Prior to that she has worked in the Spanish National Institute for Aerospace Technology (INTA). She holds a Ph.D. in Computer Science as well as a M.Sc. in Statistics and Operational Research. Her main research areas are Applied Multivariate Analysis, Fuzzy Implications, ICT use in education and Health Economics. In addition to her research publications, she has published several manuals on Decision Analysis and basic Statistics. She has participated in several projects and consulting contracts with private companies.

Andrés L. Cancer is a Telecommunication Engineer specialized in network management and diagnosis of telecommunication services with over 25 years of experience in these areas. He also holds a M.Sc in Research. His range of research interest encompasses network management, service diagnosis, education and data processing. He has different works published in these areas.

\section{Authors and Affiliations}

\section{Pilar López-Sánchez ${ }^{1}\left(\mathbb{0} \cdot\right.$ Elena Urquía-Grande ${ }^{2}\left(\mathbb{D} \cdot\right.$ Cristina del Campo $^{2}(\mathbb{D})$ Andrés L. Cancer ${ }^{3}$}

Elena Urquía-Grande

eurquiag@ucm.es

Cristina del Campo

campocc@ucm.es

Andrés L. Cancer

andres.1.cancer@gmail.com

1 Universidad Francisco de Vitoria, Madrid, Spain

2 Universidad Complutense de Madrid, Madrid, Spain

3 INDRA Systems, Madrid, Spain 